\title{
The Implementation Of Regional Authority Of West Java Province In The Sea In 2017
}

\author{
Ufa Anita Afrilia \\ Department of Government Science Padjadjaran University, \\ Bandung, Indonesia \\ Nandang Alamsah Deliarnoor \\ Department of Government Science Padjadjaran University, \\ Bandung, Indonesia
}

\begin{abstract}
The Law Number 23 of 2014 concerning Regional Government, which among others regulates the extension of authority of the Province in the maritime sector, removes the authority of the District / Municipal over the supervision of the sea and fully submitted to the Province shall come into force effective by 2017. If the original authority of the Province from 4-12 miles is now expanded to 0-12 miles. One of the implications of this policy is the increasingly difficult oversight at sea. With limited budgets and human resources, this policy is doubtful of its effectiveness, besides its application there could be the possibility of emergence of problems due to changes in authority in the marine sector whether there is an impact on the local government of the District / City and on the community. This is interesting to study, this research was conducted to see the implementation of regional authority of West Java Province in the sea in 2017. This research uses descriptive research method with qualitative approach. The results showed that with the shift of authority affairs of West Java Province in the sea, problems arose because of the limited human resources, funds, facilities and infrastructure, and the range of control that is too far so that the handling of problems that arise in exercising the authority of the province in the sea becomes longer. Based on the above exposure, it can be concluded that the implementation of regional authority of West Java Province in the sea in 2017 is not optimal. There should be a synchronization of laws and regulations that clearly regulate the authority among the implementing agencies of regional authority of West Java Province on the Sea, and on the obligation to establish zoning regulation originally based on District / City to become Province based.
\end{abstract}

Keywords: Authority; Implementation; Implemention of Authority; Implementation of Regional Authority.

\section{PREFACE}

Republic of Indonesia is an archipelagic country that has abundant natural resources for the whole nation, must be maintained and managed sustainably for the benefit of present and future generations. As an archipelagic country with an area of 5.8 million $\mathrm{km}^{2}$ of sea that consists of territorial waters of 3.1 million $\mathrm{km}^{2}$ and ZEE Indonesia $2.7 \mathrm{~km}^{2}$ and consists of 17,508 islands with a beach that lengths for $104,000 \mathrm{~km}$. Indonesia has various potentials of very rich natural resources, therefore a law that protects and regulates the entire sector related to marine resources in an integrated manner.

Law No. 32 of 2004 is no longer in accordance with the needs of regional government governance that continues to grow. Then, the Law No. 23 of 2014 issued, that the governance authority being delegated to the Province level. In line with the principle is also implemented the autonomy principle in natural resources which the provincial is actually responsible. The 
principle of real autonomy is a principle that to handle governmental affairs in the Province level carried out based on the tasks, authorities and obligations that actually exist and have the potential to grow, live and develop in accordance with the potential and uniqueness of the region. The meaning of responsible autonomy is provincial-based autonomy which in its implementation must be completely in line with the purpose and intent of granting autonomy, which is basically to empower the region including improving the welfare of the people who are the main part of the national goal. With regard to the authority of marine area management, Law No. 23 of 2014 Article 27 that provinces are authorized to manage natural resources at sea in their territory. The provincial authority to manage natural resources at sea includes:
a. exploration, exploitation, conservation and management of marine resources outside of oil and gas;
b. administrative arrangements;
c. spatial arrangements;
d. participate in maintaining security at sea; and
e. participate in maintaining state sovereignty.

The authority of the Provincial Region to manage natural resources at sea as referred to in paragraph (1) shall be at most 12 (twelve) nautical miles measured from the coastline towards the open sea and / or towards the archipelagic waters. If the territorial sea between the two Provinces is less than 24 (twenty four) miles, the authority to manage natural resources at sea is spaced equally or measured in accordance with the principle of the midline of the region between these two Provinces. The provisions do not apply to fishing by small fishermen.

Provincial Terriri Province has the authority to manage natural resources at sea. The Provincial Territory of the Province shall be assigned by the Central Government to exercise the authority of the Central Government in the field of marine based on the Task Assistance principle. Thus the District / Municipal Government no longer has the authority to manage the resources at sea. Through Law No. 23 of 2014 Provincial Government has a very important role in the utilization of all the potential that exists to fill the national development in general and in particular regional development towards the welfare of the people against the various potential of marine resources it has.

Law No. 23 of 2014, which among others regulate the extension of provincial authority in marine sector to become effective in 2017. The authority of the province, then from 4-12 miles, now expanded to 0-12 miles. One of the implications of this policy is the increasingly difficult oversight at sea. Law No. 23 of 2014, among others, removes the authority of districts / municipalities over the supervision of the sea and fully submitted to the province. With limited budget and human resources, this policy is doubtful of its effectiveness. in addition to the implementation there could be the possibility of the emergence of problems due to changes in authority in the marine sector whether there is an impact on the local government of the district/municipal and on the community.

The problems caused by the lack of supervision of the sea in the Province of West Java, among which is the problem of sea water pollution into the main constraint of shrimp farming in Cirebon district of West Java. Next comes the problems of seaweed quality decline due to seawater contamination in Kampung Nelayan Pal Jaya, Segera Jaya, Taruma Jaya, Bekasi District, West Java. Pollution of sea water in marine waters of West Java region has become a barrier of shrimp farming, which shrimp cultivation as export commodity, as well as reducing the quality of seaweed so as to disrupt the income of the community economy. 
The above shows that with the enactment of Law No. 23 of 2014, there are still problems and have not found a solution. Law No. 23 of 2014 which became the authority of the province became 0-12 miles, resulting in more difficult oversight at sea. The Central and Provincial Governments's attention due to vulnerable coastal areas is damaged by the activities of insiders utilizing resources or natural disasters on the one hand and on the other side of the accumulation of partial or sectoral exploitation activities in coastal areas and the impact of activities others in the upper reaches of coastal areas supported by existing legislation often cause damage to marine resources. Surely the entire territorial sea should be managed and utilized as well as possible and on an ongoing basis.

Based on the explanation above, the research on the implementation of regional authority of West Java Province in the sea would be important to be examined because to discuss about how the implementation of regional authority of West Java Province in 2017 which answered various questions in this study on the authority of the province to manage natural resources at sea based on Article 27 of Law No. 23 of 2014, the problem after withdrawal of district/municipal authority managing the sea from 0-4 miles, the provincial action of preparing special equipment placed in coastal districts/municipalities, the possibility of cooperation between provinces and districts/municipality to manage marine, and on the existence of regencies/municipalities indicated to have problems regarding marine management. This study aims to analyze and describe the implementation of regional authority of JavaBarat Province in the sea in 2017, and to see if any problems or conflicts arise, and prospects or things that may occur in a case that has the potential to cause certain impact in the implementation of provincial authority West Java Province at sea.

\section{RESEARCH METHODS}

The method used is qualitative research method. The research tries to explain in detail and conduct an in-depth analysis related to the implementation of regional authority in the sea in the implementation of autonomy and local development in realizing the welfare of the people in the region, especially West Java. The data needed in this study consists of two types namely primary data and secondary data. Primary data is data / information obtained directly from informants / resource persons who understand the research problem. Primary data can be obtained through interviews and Focussed Group Discussion (FGD). While the secondary data is data that has been processed in the form of data numbers or facts.

In qualitative research methods data analysis is generally done ongoing throughout the process of data search and research it takes place. This means that data analysis is done during the research process since the data collection was done. To analyze the data, two main sources were used, ie the research questions (evaluation) that had been formulated and the analytical insights and interpretations that emerged during the data collection. As well as analysis and interpretation based on specific focus based on information from all key informants and other data sources.

Qualitative data analysis techniques used in this study, consisting of three main activities that occur simultaneously, namely: data reduction, data presentation, drawing conclusions. From the analysis, the authors do the interpretation of data on research that is not solely aimed at the description solely, but the authors will try to do eksplanasi, by developing further analysis of the general description of research. In terms of testing the validity of the data, the researcher uses triangulation of data and sources, data that has been collected through interviews from different sources of informants both from government apparatus groups, communities, interest groups, and experts who understand the research problem. Triangulation is also done 
through various observations, and analysis of documents so that will be reviewed the pattern of connectedness.

\section{RESULTS AND DISCUSSION}

Implementation of the authority of both central, provincial and district/municipal governments is based on the distribution of government affairs. Based on Law No. 23 of 2014 on Regional Government, government affairs are divided into absolute affairs, concurrent affairs, and general government affairs. Implementation of absolute affairs is a matter entirely the authority of the central government, general government affairs is a matter of government which became the authority of the president as head of government. While the concurrent affairs into a common affair in the share of the authority of central government, provincial, and district/municipal. Concurrent affairs submitted to the regions became the basis for the implementation of regional autonomy. The limits of central, provincial and district/municipal authorities for the implementation of this concurrent affair will be more easily understood if arranged in the table below:

Table 1.1.

Authority Boundaries Between the Central, Provincial, and District/Municipal Government Level

\begin{tabular}{|c|c|c|}
\hline \multicolumn{3}{|c|}{ Authority } \\
\hline Central & Provincial & District/Municipal \\
\hline $\begin{array}{l}\text { a. Government Affairs } \\
\text { whose locations cross } \\
\text { provincial or cross- } \\
\text { border areas; } \\
\text { b. Government Affairs } \\
\text { whose users cross } \\
\text { provincial or cross- } \\
\text { border areas; } \\
\text { c. Government Affairs } \\
\text { whose benefits or } \\
\text { negative impacts cross } \\
\text { provincial or cross- } \\
\text { border areas; } \\
\text { d. Government Affairs } \\
\text { whose use of resources } \\
\text { is more efficient if } \\
\text { carried out by the } \\
\text { Central Government; } \\
\text { and /or } \\
\text { e. Government Affairs } \\
\text { whose role is strategic } \\
\text { for the national } \\
\text { interest. }\end{array}$ & $\begin{array}{l}\text { a. Government Affairs } \\
\text { whose locations cross } \\
\text { the } \\
\text { regencies/municipals; } \\
\text { b. Government Affairs } \\
\text { whose users cross } \\
\text { regencies/ municipals; } \\
\text { c. Government Affairs } \\
\text { with benefits or } \\
\text { negative impacts across } \\
\text { regencies/ } \\
\text { municipalities; and / or } \\
\text { d. Government Affairs } \\
\text { whose use of resources } \\
\text { is more efficient if } \\
\text { carried out by the } \\
\text { Provincial Region. }\end{array}$ & $\begin{array}{ll}\text { a. Government Affairs } \\
\text { whose location within } \\
\text { the regency/ municipal } \\
\text { Region; } \\
\text { b. } \text { Government Affairs } \\
\text { whose users are in } \\
\text { regencies/ } \\
\text { municipalities; } \\
\text { c. } \text { Government Affairs } \\
\text { whose benefits or } \\
\text { negative impacts are } \\
\text { only within the } \\
\text { regencies/municipalities } \\
\text {; and/or } \\
\text { d. Government Affairs } \\
\text { whose use of resources } \\
\text { is more efficient when } \\
\text { undertaken by } \\
\text { regencies/Municipalities } \\
\text {. }\end{array}$ \\
\hline
\end{tabular}

Sumber : Law No. 23 of 2014 (researchers, 2017)

Article 9 paragraph (1) of Law no. 23 of 2014 classifies Government Affairs consisting of absolute government affairs, concurrent government affairs, and general government affairs. Furthermore, in Article 9 paragraph (3) states that the affairs of the concurrent government as referred to in paragraph (1) shall be Government Affairs divided between Central and Regional Government Province and district/municipal Region. Article 9 paragraph (4) states that the concurrent government affairs which are submitted to the Region shall be the basis for the 
implementation of Regional Autonomy. Concurrent government affairs are then divided into regional authorities consisting of the Mandatory Government Affairs and Preferred Government Affairs. One of the affairs of the Preferred Government includes marine and fisheries (Article 11ayat (1)).

Article 14 paragraph (1) of Law no. 23 of 2014 states that the Implementation of Government Affairs in the fields of forestry, marine, and energy and mineral resources are shared between the Central Government and Provincial Region. In Article 14 paragraph (5) it is mentioned that the producing and non-producing district/municipal Region obtains revenue sharing from the implementation of Government Affairs as referred to in paragraph (1), and in paragraph (5) thereafter regulated the determination of the producing district/municipal Region for the calculation of marine profit sharing is a marine product within the boundary of 4 (four) miles measured from the coastline towards the high seas and/or towards the archipelagic waters. How is the implementation implementation of government affairs in the field of forestry, marine, and energy and mineral resources are only divided between the Central Government and Provincial Region, whereas in the case of calculating the share of marine resources there is a portion of District Government/Municipal? How is the implementation of the authority of the Provincial Region at sea mentioned in Article 27 paragraph (1) in which Provincial Region is authorized to manage natural resources at sea in its territory? UU no. 23 of 2014 only regulates territory the management which becomes the authority of the Provincial Region as mentioned in Article 27 paragraph (3) where the authority of marine management of the Provincial Region shall be set furthest 12 nautical miles measured from the coastline towards the open sea and or towards the waters of the archipelago. With the enactment of Law No. 23 of 2014, there is a change of authority of the sea management of the Province which originally from 4 to 12 miles has now become $0-12$ miles, the water management conducted previously by the District / Municipal Government is taken over by the Provincial Government, one of the authority of the sea zonation which used to be 4-12 miles, is now 0-12 miles away. Previous zone 0-4 miles into the authority of the District/Municipal Government. To the marine management in the region, there are four types / regimes of SDA ownership, namely a. State property regimes, b. Public property regimes, c. Private property regimes, d. Common property regimes (oppen acces). 2 Each regime of ownership or control of these resources also determines how the management is done, therefore the division of authority between the Central Government and the Regions should be done with due regard to the rights of indigenous peoples, especially the sea tenure which is constitutionally recognized in Article 18B paragraph (2) of the 1945 Constitution of the Republic of Indonesia, especially in its management arrangements which are currently regulated in Article 29 paragraph (5) of Law No. 23 of 2014.

Authority, meant by the Indonesian Dictionary (KBBI) is: 1. matter of authority; 2. the rights and powers that it has to do something. 2. Division of Authority, which is meant by the division of authority is as referred to in the Elucidation of Law No. 23 of 2014, namely the granting of authority to regulate and manage their own Government Affairs granted by the Central Government to the Region and in the implementation carried out by the head of the region and DPRD assisted by the Regional Devices. Law No. 23 of 2014, which among others regulate the extension of provincial authority in marine sector to become effective in 2017. If the authority of the province from 4-12 miles is now expanded to 0-12 miles. Law No. 23 of 2014 on Regional Government, among others, removes the authority of districts/municipalities over the supervision of the sea and fully submitted to the province.

After the Act No. 23 of 2014 the authority of the marine area of West Java Province is $0-12$ miles, the authority of 0 miles is calculated from $100 \mathrm{~m}$ highs. Provincial Authority to manage 
natural resources at sea such as exploration authority, exploitation, conservation and management of marine resources outside oil and gas, administrative arrangements, spatial arrangements; security at sea, and in maintaining state sovereignty.

Marine and fishery services take care of marine and fishery affairs. Do all coastal communities have to be fostered, the answer is no. Because talking with the marine is also associated with other agencies such as the Department of Transportation, Forest Service, and other services. All authority obtained by the Office of Marine and Fisheries is just about the actual zero-twelve zoning of what the Maritime and Fishery Service should target eg a license or a recommendation. Many of the authorities have been disbursed by other agencies, the recently born marine is following the existing rules. With the remnants of authority already shared with other agencies, for example, protected forest has become the authority of the forestry service. There should be a clear authority what should be done by the Department of Marine and Fisheries because it is divided with other agencies. So there must be synchronization rules.

There are several problems that occurred after the withdrawal of the authority of the District / Municipal which manages the sea from 0-4 miles. With the transfer of provincial authority affairs, problems arise such as:

1. Human resources are limited, because the transfer of irregular personnel in the Perka BKN so that employee status is still in the District / Municipal.

2. Limited facilities and infrastructure, because not all of the assets of districts / municipalities related to authority affairs are transferred to the Province.

3. Range of control that is too far so that the handling of cases becomes longer, this is because the service has no branch offices in each District / Municipal only form 4 (four) branches of service.

There is a provincial effort to set up special equipment placed in coastal districts / cities. The input from the Office of Marine and Fisheries of West Java Province is the first institution that was prepared. The Office of Marine and Fisheries of West Java Province proposes 4 (four) branch offices in the area of Pantura (North Coast) and Pansela (South Beach) of West Java in accordance with provincial authority affairs as follows;

a. Branch Office of Marine Region I, covering the work area of Sukabumi and Cianjur.

b. Branch Office of Marine Region II, covering the work area purwakarta, subang, bekasi, and karawang

c. Branch Office of Marine Region III, covering the work area of cirebin, kote cirebon, and indramayu.

d. Branch Office of Marine Region IV, covering the work area tasikmalaya, arrowroot, and pangandaran.

Previously already existing UPTD, the proposal for the establishment of the Regional Office Branch because UPTD only carry out a special affairs while the Branch Office became the representative of the Department of Marine and Fisheries in the region. The Office of Marine and Fisheries of West Java Province filed the establishment of the Branch Office in the four areas with the purpose of Branch Office is only doing marine affairs is not another matter.

Regarding the possibility of cooperation between provinces and districts / municipalities to manage the marine, the Department of Marine and Fisheries that currently does not exist, in the future there is possible cooperation between districts / cities and provinces.

The form of coordination conducted by provinces and districts / municipalities to manage marine is the coordination done on data requests related to the preparation of zonation plans. 
The provincial authority is $0-12$ miles which is the original attribution or authority. There will be a Governor Regulation regarding delegation to the district / municipal. There is a principle of co-administration, deconcentration, decentralization. The provincial affairs undertaken by districts / municipalities is by "co-administration", with the provincial record assigning tasks, for example on the construction of fish landing which has so far enabled the cooperation of municipal districts with provinces. Provincial affairs undertaken by districts / municipalities then funded are provinces, and the bupati remains accountable to the governor.

Supervision is done in the form of provincial and district / municipal coordination. Socialization of the community also carried out coordination of districts / municipalities with the province, because although the affairs of the province but the community remains the community district / municipal. In connection with the matter of the provincial authority to manage natural resources at sea, such as:

a. Exploration, exploitation, conservation, and management of marine resources outside of oil and gas.

b. Administrative settings;

c. Spatial arrangement

d. Participate in maintaining security at sea

e. Participate in maintaining state sovereignty.

The authority of the Provincial Region to manage natural resources at sea as referred to in paragraph (1) shall be at most 12 (twelve) nautical miles measured from the coastline towards the open sea and / or towards the archipelagic waters. If the territorial sea between the two Provinces is less than 24 (twenty four) miles, the authority to manage natural resources at sea is spaced equally or measured in accordance with the principle of the midline of the region between these two Provinces. The provisions do not apply to fishing by small fishermen.

Provincial Areas characterized by islands have the authority to manage natural resources at sea. The Provincial Territory of the Province shall be assigned by the Central Government to exercise the authority of the Central Government in the field of marine based on the Task Assistance principle. Assignment is implemented after the Provincial Government of the Province of the Islands meet the norms, standards, procedures, and criteria set by the Central Government. To support the implementation of governance in Provinces of the Islands Province, the Central Government in preparing development plans and set policies DAU and DAK should pay attention to Regions Province of the Islands. The determination of DAU policy is done by calculating the ocean area which is the authority of Provincial Terrestrial Region in the management of natural resources in the sea area. In establishing DAK policies, the Central Government should take into account the development of the Island-Specified Provincial Region as an activity in the context of achieving national priorities based on territoriality. Based on the allocation of DAU and DAK, the Provincial Territorial Region develops a strategy for accelerating regional development based on the provisions of legislation. Acceleration strategies for regional development include development priorities and management of natural resources at sea, acceleration of economic development, socio-cultural development, human resource development, customary law development related to marine management, and community participation in the development of the Island Province Province. In order to support the acceleration of development in Provincial Territories, the Central Government may allocate accelerated funds outside DAU and DAK.

In accordance with the provincial authority in the annex of Law No. 23 Of 2014, among others:

- Management of ocean spaces up to 12 miles beyond oil and gas;

- Issuance of sea space permits and utilization under 12 miles beyond oil and gas 
- Empowerment of coastal communities and small islands

From the authority of the region is translated into the affairs of the constituent government which is the authority of the provinces, which are:

a. Preparation of a strategic plan, zoning plan, management plan, and action plan for management of coastal areas and smallest islands.

b. Management of area watershed conservation area, coastal conservation area and small islands, and conservation of fish species and genetic of local fish with their ecosystem.

c. Provision of broodstock and seeds and health services of saltwater and brackish fish in coastal and small islands.

d. Provision of infrastructure and facilities for the cultivation of saltwater and brackish fish in coastal and small islands.

e. Rehabilitation of coastal waters and small islands.

f. Control of sea space utilization up to 12 nautical miles from shoreline, except for the authority of the central government.

g. Increased knowledge, competence in the field of marine and fisheries, and community involvement, as well as providing support for strengthening, and institutional development of coastal communities and small islands.

h. Facilitation of business partnerships, access to technology, and information on coastal communities and small islands.

Activities undertaken by the branch of the marine service, among others:

1. Determination of conservation areas of coastal areas and small islands.

2. Technical recommendations for the issuance of non-energy seawater permits and shipload cargo (BMKT).

3. Technical recommendations for the issuance of permit arrangements for pipelines and submarine cables

4. Technical recommendations for the issuance of marine aquaculture permits

5. Technical recommendations for the issuance of marine tourism licenses

6. Provision of marine aquaculture technology and brackish water

7. Sea fish and brackish water cultivation training.

There should be government courage to moratorium or limit the no. of ships, because in reality at $0-12$ miles in the sea there is often conflict between fishermen. The no. of ships should be limited must first permit a new ship, not for the vessel just make a permit like that which often happens. There should be an arrangement because of how to explore the ocean's wealth by arranging the no. of ships or fishermen in accordance with the wealth of marine resources and what kind of fishing gear is permitted to exploit and extract the marine wealth of fish. Marine territory must be on guard because one day the fish will run out.

Associated with the change of authority of marine management between district / municipality and province is no conflict, the district / municipality is happy because the facilities and infrastructure of the provinces are wake up but the auction and levy goes to the district / municipal. As for example regarding the docking ship (docking) retribusinya entered into the province, the authority is there but until now has not been implemented.

Discussing the spatial planning in the sea, how exactly the coordination of the Office of Marine and Fisheries with the Office of Spatial Planning. To get to the main spatial layers by the Department of Highways. Once up to the sea, the spatial arrangement by the Marine Service. There is a Coordinating Agency for Regional Arrangement. Spatial arrangements in the sea still have to see the layout on the land. So that it can synchronize land and sea development. Zoning 
from 0-12 miles is a calculation of 0 starting from the $100 \mathrm{~m}$ high tide of the sea. The coastal boundary, the outer side of 12 miles equals the outermost outer line, the provincial line of authority and the territorial line. The beach is set by the district / municipal, so to calculate the zonation and do the development see on land first dijadika what for example in Pangandaran there is a conservation area and there is a fish landing base.

The design already exists with various problems, the map already exists for the conservation area for example about the turtle being the area of provincial authority. Various problems that occur are:

a. In Pangandaran there was a conflict between fishermen and conservation areas, ie there are turtles that died because of fishing nets.

b. At Ujung Genteng there was also a conflict because there were dead turtles.

c. In Cirebon conflicts over fishing equipment are prohibited.

Regarding how to arrange spatial in the sea there are several zones namely cultivation zonation, conservation zonation and general utilization zonation. The regulation on how to regulate the reclamation is the province. As for the case of reclamation in Bekasi, the sea will be dammed until derah bekasi oelh PT. Marunda will reclaim the beach, and as for Nusamanuk Tasikmalaya. Reclamation must be viewed first zonation. The arrangement of marine spatial arrangements has not yet been regulated, still using the old Regulation No. 16 of 2013, the old authority still governing the provincial authority from 4-12 miles. The new regulation is still in the process of arranging at sea regarding conservation areas, core areas, general use areas, fisheries, oil and gas, DRDKP.

As for the KSN is the National Strategic Area, the case of reclamation that occurred in Bekasi and Nusamanuk Cimanuk Tasikmalaya licensing should be to the Central Government, the Province only provide recommendations to the Central. If under 12 miles later who gave permission is the Province. Reclamation of sea embankment at marunda estuary to tip of bekasi approximately $400 \mathrm{~m}$. The 0 mile coastline is calculated from the highest tide point, the reference being the BIG map (Geospatial Information Agency) in Cibinong, if East Java has its own map. Further problems also arise in some areas, including:

a. The case in Karawang is about oil and gas in the sea, oil and gas is excluded, so the rules must follow oil and gas, in this case pertamina do notification and compensation in case of leakage.

b. A case in Pantura regarding such authority in cilamaya.

c. The case in Sukabumi there is a military training area, the ammunition disposal of the rest of the military training.

As has been previously stated that the authority of the province at sea like the remnants of authority from the other service. Because the authority of the Office of Marine Affairs and Fisheries is outdone by other Dinas that also exist in relation to the ocean.

In relation to the matter where the provincial sea authority is returned to the district / municipal, the response is welcome only, for the reason that the transfer of the maritime authority to the province is due to the presence or multiple conflicts. Between other provinces and provinces there is coordination, so it must be synchronized. If there is no administrative boundary at sea, such as on the boundary of West Java and DKI Jakarta it follows the local regulations in DKI, the Government Regulation governing Kepulauan Seribu.

The Department of Maritime Affairs and Fisheries of West Java Province Coordinate also with the Marine Supervisory Agency, such as fisheries whether there is damage to marine 
conservation, about illegal fishing, turtles are disturbed because fishing activities lobsters and so on. The water police are cracking down on the sea. Indonesia's ideals to be the maritime axis of the world is good, the importance of the state provides clarity between the central and district/municipal authorities. Must be executed and realized not only be a slogan only. But it must be supported by Human Resources and its funding. So that sovereignty awake and realize the prosperity of society, especially fisherman.

The management of marine resources can not be denied there are still many problems that become dynamics in the implementation of government. The issue of marine resources becomes very important when it is associated with the implementation of regional autonomy. The ability of local governments to manage and utilize these marine resources will have an impact on local financial management. The authority of the management of marine resources that has been seemingly ignoring coordination between levels of government becomes an empirical fact for the government in realizing sustainable environmental development. The role of the provincial government which is expected to be central in the management of marine resources in the province level, has not been able to be realized in accordance with expectations. Cooperation between the government and stakeholders in the region as an effort to engage stakeholders has not materialized as mandated in the Constitution of the Republic of Indonesia in 1945. The authority in the management of marine resources owned by the provincial government needs to be synergized with the stakeholders. So it can help the implementation of regional authority of West Java Province in the Sea.

\section{CONCLUSION}

The marine territory as the largest part of the territory of Indonesia having strategic position and value from various aspects of life which includes political, economic, socio-cultural, defense and security, and ecology, is the basic capital for the welfare and prosperity of Indonesian people. Indonesia is an archipelagic country in the form of a unified state with the insight of the archipelago needs to have a new paradigm of the future of Indonesia that is more oriented to the vision of marine development in all fields. To achieve optimum utilization of abundant marine natural resources, existing sectoral marine sector legislation requires a comprehensive and integrated management policy.

Human resources, facilities, and synchronization of laws and regulations are needed. Regional marine management will be more prudent when handled by engaging local indigenous and tribal peoples to avoid conflicts in the use of marine resources. There should be synergy between stakeholders in the implementation of provincial authority at sea so that the implementation of regional authority in the sea works, the welfare of society recognized, and make Indonesia become the maritime axis of the world.

\section{BIBLIOGRAPHY}

Deliarnoor, Nandang Alamsah. 2017, Governance Law, Bandung: UNPAD Press

Imam Subekti, Implications of Marine Fisheries Resources Management in Indonesia Based on the Code of Conduct for Responsible Fisheries (CCRF) (2010) 4: 1 perspective 7, pp. 7.

Roestoto Hartojo Putro. 2009. Implementation of Local Government Policy in Sea Fishery Resources Management in Lamongan, East Java. Surabaya: Department of Administrative Sciences, FISIP, Airlangga University.

Sunyowati, Dina. 2008. Legal Framework for Coastal Area Management Based on the Concept of Integrated Coastal Management in the Framework of Sustainable Marine Development, Summary of Dissertation. Surabaya: Postgraduate Program of Airlangga University. p. 16.

Supratikta, Hadi. 2015. Legal Assessment of the Division of Central and Regional Authorities in Sea Management. Center for Research and Development of National Law System. National Legal Development Board of the Ministry of Justice and Human Rights of the Republic of Indonesia. 
Afrilia' U. A., \& Deliarnoor, N. A. (2018). The Implementation Of Regional Authority Of West Java Province In The Sea In 2017. Advances in Social Sciences Research Journal, 5(3) 198-208.

(www.bphn.go.id/data/.../kewenangan_pusat_daerah_dlm_pengelolaan_laut.pdf, accessed on 19 November 2017 at $05.00 \mathrm{WIB}$ )

Syafrudin, Ateng. 2000. Toward the Implementation of a Clean and Responsible State Government. Pro Justisia Journal Edition IV. Bandung: Parahyangan University

https://news.detik.com/foto-news/d-3418685/pilments-air-laut-kurangi-kawar-lautquality (accessed October 2nd, 2017 at $21.00 \mathrm{pm}$ )

http://industri.bisnis.com/read/20150628/99/447976/budi-daya-udang-di-jabar-terhambat-pollution-air-laut (accessed October 2nd, 2017 at 21.00 WIB)

http://dkp.jabarprov.go.id/index.php/natural-college/279-security-powering-and-lautions (accessed October 2nd, 2017 at $21.00 \mathrm{WIB}$ ) 